\title{
COVID-19 ile Mücadele Sürecinde Yerel Yönetimlerin Genel Görünümü
}

*

\author{
Asmin Kavas Bilgiç ${ }^{1}$ \\ ORCID: 0000-0001-8319-7950
}

Öz

Tüm dünya, COVID-19 salgını ile mücadele konusunda alarma geçmiş durumdadır. Salgın özellikle nüfusun yoğun olduğu kentsel alanlarda etkisini daha fazla göstermektedir. Kentsel ölçekte, vatandaşa en yakın hizmet sunmakla yetkili olan yerel yönetimlerin rolü salginla mücadelede çok önemlidir. Yerel yönetimler, tüm dünyayı etkisi altına alan COVID-19 ile mücadele sürecine destek olmak amacryla; hizmet sunma yöntemlerini ve becerilerini geliştirerek, salgının yayılımını hafifletmeyi hedeflemektedirler. COVID-19 salgını ile mücadelede yerel yönetimlerin sundukları hizmetlerin araştırılması ve yerel yönetimlerinin öneminin tartışılması bu çalışmanın temel amacın oluşturmaktadır. İçerik analizi yöntemi ile geliştirilen bu çalışma kapsamında, uluslararası bağlamada salgından en çok etkilenen yerel yönetimlerin ve Türkiye'deki 30 büyükşehir belediyesinin salgınla mücadele sürecindeki yöntem ve uygulamalarına yer verilerek; bu birimlerin önemi tartışılmaya çalışılmıştır. Çalışmanın sonuç kısmında Türkiye'de salgın döneminde merkezi idarenin, yerel yönetimlerin bazı eylem ve faaliyetlerine yönelik kontrol ve müdahalesinin fazla olduğu; buna rağmen uluslararası örnekler de dikkate alındığında yerel yönetimlerin salgınla mücadele sürecinde başarılı uygulamalara imza attı̆̆ı tespiti yapılmıştır.

Anahtar Kelimeler: COVID-19, yerel yönetimler, hizmet, müdahale, ihtiyaç

\footnotetext{
${ }^{1}$ Dr. Öğr. Üyesi, Eskişehir Osmangazi Üniversitesi, E-mail: asmin.kavasbilgic@ogu.edu.tr idealkent (c) Kent Araştırmaları Dergisi (Journal of Urban Studies) http://idealkentdergisi.com 


\title{
Overview of the Local Governments in the Process of Combating COVID-19
}

\author{
Asmin Kavas Bilgiç 2 \\ ORCID: 0000-0001-8319-7950
}

\begin{abstract}
The whole world is alarmed about the fight against the COVID-19 pandemic. The epidemic has a greater impact especially in urban areas with high population. The role of local governments, which are authorized to provide closest service to the citizen at the urban scale, is very important in combating the pandemic. Local governments aim to mitigate the spread of COVID19 by improving service. The main purpose of this study is to research the services provided by local governments in combating the COVID-19 pandemic and to discuss the importance of local governments. This study was carried out using content analysis method. In this study, the municipalities that make up the international best practices and 30 metropolitan municipalities in Turkey are given to the methods and practices in the process of fighting the epidemic. As an output of the study, during the pandemic, the central government, which has control over the local government on some actions and activities, in Turkey. Nevertheless, considering international examples, it has been determined that local governments have made successful practices in the process of combating the pandemic.
\end{abstract}

Keywords: COVID-19, local governments, service, intervention, needs

2 Asst. Prof. Eskişehir Osmangazi University, E-mail: asmin.kavasbilgic@ogu.edu.tr

idealkent (c) Kent Araştırmaları Dergisi (Journal of Urban Studies)

http://idealkentdergisi.com

Geliş Tarihi Received Date: 27.10.2020 Kabul Tarihi Accepted Date: 28.12.2020 


\section{Giriş}

COVID-19 olarak da bilinen yeni tip Koronovirüsün, pandemi olarak nitelendirildiği 11 Mart 2020 tarihinden bu yana tüm dünya, salgınla mücadele konusunda alarma geçmiş durumdadır. Başta hükümetler olmak üzere yerel yönetim birimleri, uluslararası kurum ve kuruluşlar geliştirdikleri ve geliştirmeye devam ettikleri çözümler ile salgınla mücadelenin yollarını aramaktadırlar. Bugün dünya nüfusun yüzde 55'i kentsel alanlarda yaşamaktadır. Salgin da özellikle nüfusun yoğun olduğu bu kentsel alanlarda etkisini daha fazla göstermektedir. Kentsel ölçekte, vatandaşa en yakın hizmet sunmakla yetkili olan yerel yönetimlerin rolü salgınla mücadelede çok önemlidir. Bu doğrultuda da dünya genelinde yerel yönetimlerin salginla mücadeleye destek olmak amaciyla hizmet sunma yöntemlerini ve becerilerini geliştirerek, COVID-19'un yayılımını hafifletmeyi hedefledikleri görülmektedir. Küresel ölçekte yaşanan sorunlara karşı yerel düzeyde çözümler sunmanın önemi, COVID-19 salgını ile beraber daha çok ön plana çıkmıştır. Bu süreçte merkezi hükümetler tarafından büyük ölçekli merkezi politikalar üretmek yerine; temel ihtiyaçlara karşı yerel dinamikler gözetilerek yerel yönetimler tarafından geliştirilen özgün, hızlı ve etkili çözümlerin önemi bir kez daha anlaşılmıştır (Bayraktar, 2020).

Yerel yönetimler, vatandaşa en yakın hizmet sunan ve onların yaşamına doğrudan etkide bulunan önemli yönetsel birimlerdir (Gözübüyük, 2008: 154-156). Dolayısıyla yerel yönetimler yerel düzeyde temel ihtiyaçlara yönelik çözüm önerileri sunmayı, merkezi idareye göre daha hılı ve etkili bir şekilde gerçekleştirebilmektedirler. Bu durum da tüm dünyayı etkisi altına alan salgın döneminde yerel yönetimlerin önemini bir kez daha ortaya çıkarmaktadır. COVID-19 salgınında yerel yönetimlerin önemini tartışmak adına bu çalışma kapsamında da temel olarak “Uluslararası arenada ve Türkiye' de nüfusun büyük bir kısmına ev sahipliği yapan büyükşehir belediyeleri, salgınla mücadele sürecine hangi hizmetleri sunarak destek vermektedirler?" sorusuna yanıt aranmıştır. Çalışma kapsamında bu sorunun yanıtı aranırken, COVID-19 salgınından en çok etkilenen ülkelerdeki yerel yönetimlerin ve Türkiye'deki 30 büyükşehir belediyesinin örnek bulguları üzerinden, hangi hizmetlerin nasıl sunulduğu ve yürütüldüğüne yer verilmeye çalışılmıştır. Bu doğrultuda çalışmanın temel amacı, tüm dünyayı etkisi altına alan salgınla mücadele kapsamında, yerel yönetimler tarafından sunulan hizmetlerin araştırılmasıdır. Çalışma kapsamında Türkiye'de nüfusun neredeyse 
yüzde 78 'ine ev sahipliği yapan büyükşehir belediyelerinin salgınla mücadele kapsamında sundukları hizmetler ayrıntılı olarak araştırılmıştır. Çalışmanın temel hedefi salgınla mücadele konusunda Türkiye'de ve dünyada önemli bir yere sahip olan yerel yönetimlerin salgınla mücadeleye yönelik politika ve faaliyet alanların tespit ederek, genel çıkarımlarda bulunmak ve bu alana yönelik ilgili tüm paydaşların katılımlarının sağlanabileceği yeni bir politika diyaloğunun geliştirilmesine katkı sunmaktır.

Türkiye'de COVID-19 salgını ile mücadele kapsamında yerel yönetimlerin öneminin tartışıldığı çalışmaların sayısının sınırlı olduğu gözlemlenmektedir. Sınırlı sayıdaki bu araştırmalardan ilkini "Pandemide ve Sonrasında Yerel Yönetimler İçin Politika Önerileri” başlıklı çalışma oluşturmaktadır. Bu çalışma kapsamında COVID-19 sürecinde belediyeler tarafından sunulan hizmetlere değinilmiş ve ileriki dönemler için belediyelerin izleyecekleri politikalara dair önerilerin üzerinde durulmuştur (Bayraktar, 2020). "Yerel Yönetimlerin Pandemiyle Mücadelesi" kapsamında 5 farklı seri olarak yayımlanan araştırma yazısı, bu alandaki diğer örnek çalışmalardan bir diğerini oluşturmaktadır. Çalışma kapsamında salgın döneminde İstanbul, İzmir ve Gaziantep Büyükşehir belediyelerinin faaliyet alanlarına ve salgın sürecinde yerel yönetimler ile sivil toplum işbirliğinin güçlendirilmesine yönelik politika önerilerine yer verilmiştir (Sivil Sayfalar, 2020a). “Türkiye'de Koronavirüs Günleri: Despotik Leviathan'ın Gölgesinde Yönetişim Kavramını Düşünmek" başlıklı araştırma yazısı ise merkezi hükümet, yerel yönetimler ve sivil toplum örgütü arasında kurulabilecek güçlü bir eşgüdümün, salgınla mücadele sürecinde yakalanacak başarıda önemli bir etken olduğu üzerinde durmaktadır (Erdoğan, 2020). Uluslararası iyi uygulama örneklerini de içerecek şekilde, büyükşehir belediyelerinin salgınla mücadele yöntemlerini örnek bulgular üzerinden tartışılmasını hedefleyen araştırmaların sayısının sınırlı olması da bu alanda çalışma yapılmak istenmesinin temel nedenlerinden birisini oluşturmaktadır.

“COVID-19 ile Mücadele Sürecinde Yerel Yönetimlerin Genel Görünümü" başlıklı bu çalışma, salgın döneminde uluslararası arenada ve Türkiye'de yerel yönetimler tarafından sunulan hizmetlerin içeriği ile ilgili kapsamlı bir sinıflandırma yapmaktadır. Bununla birlikte örnek belediye bulguları üzerinden, yerel yönetimlerin salgınla mücadele sürecine verdikleri önemi tartışmayı hedefleyen çalışmanın, ileride yapılacak araştırmalara teorik bir altyapı sunması hedeflenmektedir. Bu açılardan da çalışmanın literatüre katkı yapması beklenmektedir. 
İçerik analizi yöntemi ile geliştirilen bu çalışmanın 3 kısımdan oluşmaktadır. Çalışmanın birinci kısmında uluslararası bağlamda salgından en çok etkilenen birtakım dünya ülkelerindeki yerel yönetimler tarafından geliştirilen uygulamalara ve hizmet sunum yöntemlerine yer verilmiştir. Çalışmanın ikinci kısmında Türkiye'de nüfusun yüzde 78' ine ev sahipliği yapan 30 büyükşehir belediyesinin salgınla mücadele yöntemlerine, sundukları hizmetlere ve faaliyet alanlarına değinilmiştir. Çalışma kapsamında büyükşehir belediyelerinin seçilme nedeni, Türkiye'de nüfus açısından önemli bir temsil gücüne sahip olması olarak gösterilebilir. Yine çalışmanın bu kısmında, merkezi idarenin yerel yönetimlerin süreçteki bazı eylem ve faaliyetlerine yönelik kontrol ve müdahalesinin fazla olduğuna yönelik tespitlerde bulunulmuş ve bu durum örnek uygulamalar üzerinden açıklanmaya çalışılmıştır. Çalışmanın sonuç ve genel değerlendirme bölümünü içeren üçüncü ve son kısmında yaşadığımız pandemi ile mücadele döneminde dünyadaki ve Türkiye'deki yerel yönetimlerin sunmuş oldukları hizmetler kapsamında genel bir değerlendirme yapılmış ve çalışma tamamlanmıştır.

\section{COVID-19 Salgınında Dünyada Yerel Yönetimler}

2019 yılının Aralık ayında Çin' in Wuhan kentinde, hayvan pazarından bulaştığı tahmin edilen bir virüs nedeniyle, çok sayıda hastalık olduğu duyurulmuştur. İlk olarak 12 Ocak 2020 tarihinde Dünya Sağlık Örgütü (DSÖ) tarafından Çin'de başlayan şikâyetlerin sebebinin, yeni tip bir Koronavirüs olduğu açılanmıştır. 11 Mart 2020 tarihinde DSÖ tarafından bu salgının COVID-19 pandemisi olarak nitelendirilebileceği değerlendirmesi yapılmıştır (Türkiye Bilimler Akademisi, 2020: 15). Bu tarihten itibaren salgının yaylım hızı artmış ve dünya genelinde birçok ülke, salgınla mücadele kapsamında bir dizi önlemler almaya başlamıştır.

Küresel ölçekte yaşanan sorunlara karşı yerel düzeyde çözümler sunmanın önemi, COVID-19 salgını ile beraber daha çok ön plana çıkmıştır. Bu süreçte merkezi hükümetler tarafından büyük ölçekli merkezi politikalar üretmek yerine; temel ihtiyaçlara karşı yerel dinamikler gözetilerek yerel yönetimler tarafından geliştirilen özgün, hızlı ve etkili çözümlerin önemi bir kez daha anlaşılmıştır (Bayraktar, 2020). Çalışmanın bu kısmında, COVID-19 sürecinde salgından en çok etkilenen birtakım dünya ülkelerindeki yerel yönetim örnekleri incelenmiştir. Çalışma çerçevesinde anahtar kelimeler üzerinden yapılan internet araştırmaları kapsamında tespit edilen yerel yönetimlerin, internet siteleri ve dijital kaynakları taranmış ve bu alana yönelik yürüt- 
tükleri hizmetler derlenmiştir. Yapılan bu araştırmalar kapsamında uluslararası şehir örnekleri üzerinden yerel yönetimlerin pandemi ile mücadeleye yönelik hizmetlerini, belirli başlıklar altında yürüttükleri gözlemlenmiştir. Aşağıda uluslararası örnekler üzerinden tartışılan bu hizmet başlıkları: (1) Süreçle ilgili kamuoyu bilgilendirme faaliyetleri, (2) Sosyal destek ve yardım hizmetleri, (3) Eğitim, (4) Kültür, sanat, moral ve psikolojik destek ve (5) Sağlık hizmetlerine destek gibi alanlardan oluşmaktadır.

\section{COVID-19 İle İlgili Kamuoyunu Bilgilendirme Faaliyetlerini Yürütmek}

COVID-19 salgın ile birlikte kamuoyunu bilgilendirme faaliyetlerinin önemi daha da artmıştır. Buradaki bilgilendirme faaliyetleri, yeni kurallar, tedbirler ve kısıtlamaların yanı sıra; günlük vakaların durumu, hasta ve iyileşen sayıları gibi sağlık verilerini de kapsamaktadır (Bayraktar, 2020). Uluslararası örnekler incelendiğinde, kamuoyunu bilgilendirme faaliyetlerini yürütme işlevinin daha çok yerel yönetimlerin kontrolünde gerçekleştiği dikkat çekmektedir. Örneğin İsviçre'de yerel yönetimlerin öncülüğünde acil durumlarda vatandaşları bilgilendirmek üzere 'Alet Swiss' isimli bir dijital platform kurulmuştur. Bu platform, vatandaşların acil durum alarmlarını, uyarılarını ve bilgilerini doğrudan cep telefonlarından almalarını sağlayan bir uygulamadır. Nitekim bu uygulama üzerinden yurttaşlar, cep telefonlarından günlük olarak yaşanılan salgına ilişkin vaka, hastane, yatak, yoğun bakım sayıları ve günlük araştırmalara ilişkin bilgi almaktadırlar (Alert Swiss, 2020). Bunun yanında Cenevre Kantonu kendi internet sitesi üzerinden salgına ilişkin vaka sayılarını düzenli olarak paylaşarak kamuoyunu bilgilendirmektedir (Enstitü İstanbul, 2020). Berlin Belediyesi de Cenevre Kantonu gibi kendi internet sayfası üzerinden vaka sayılarına ilişkin güncel bilgiler paylaşmaktadır. Ayrıca belediyenin salgın çerçevesinde aldığı önlemler de site üzerinden kamuoyuna duyurulmaktadır. İnternet sitesi duyurularının yanı sıra belediye tarafından 8 dilde "COVID-19 hakkında sık sorulan sorular" başliklı posterler ve bilgilendirme notları hazırlanmış ve kamuoyu ile paylaşılmıştır (The Governing Mayor of Berlin, 2020)

\section{Sosyal Destek Ve Yardim Hizmetler}

Sosyal yardım hizmetleri, sosyal devlet anlayışının bir gereği olarak merkezi hükümetin yanı sıra yerel yönetimler tarafından da çocuklar, gençler, engelliler, kadınlar, yaşlılar ve dar gelirlilere yönelik olarak sunulan her türlü sosyal içerikli faaliyetleri kapsamaktadır (Pektaş, 2010: 1-22). Pandemi döne- 
minde temel ihtiyaçlar göz önünde bulundurularak tüm dünyada sosyal yardım hizmetleri kapsamında en çok maddi yardımların yapıldığı görülmektedir. Yoksullar, işsizler, evsizler, mülteciler, esnaflar, öğrenciler gibi bu süreçten en çok etkilenen kesimlere, hem merkezi hem de yerel düzeyde yardım faaliyetleri yapılmaktadır. Örneğin Barselona Belediyesi tarafından COVID19 salgınında özellikle dar gelirli ailelerin barınma haklarını güvence altına alabilmek için kira ödemelerinde devlet yardımlarına ek olarak 2,5 milyon avroluk bir belediye katkısı yapılmıştır (Barcelona.Cat, 2020). Maddi yardımların yanı sıra yeterli beslenme imkanı bulamayanlara yönelik olarak gıda yardımları, bu dönemde özellikle yerel yönetimler tarafından yapılan diğer yardım türleri arasındadır (Bayraktar, 2020). Bu bağlamda Helsinki Belediyesi tarafından yapılan yardımlar dikkat çekmektedir. Belediye hizmet sınırları içerisinde evsizler için kentin 9 farklı bölgesinde gıda dağıtım noktası oluşturularak; gıda yardımlarına destek verilmeye çalışmıştır (City of Helsinki, 2020).

Maddi ve gıda yardımlarının yanında bu süreçte yerel yönetimler, evlerinden çıamayan insanların ihtiyaçlarının karşılanması, sokak hayvanlarının beslenmesine destek verilmesi, evsizlere geçici konaklama yerlerinin sağlanması gibi birçok iyi uygulamayı da hayata geçirmişlerdir (Kap, 2020a). Örneğin New York Belediyesi, COVID-19 süreci ile beraber kent merkezinde ve metrolarda yaşayan evsiz kişileri, kentin çeşitli bölgelerindeki sığınma evlerine ve otellere yerleştirmiştir (Amerika'nın Sesi, 2020). Yine benzer şekilde Londra Belediyesi tarafından sayıları 1000'den fazla olan evsizin merkezdeki otellere yerleştirildiği ve bu hizmet alanına 10 milyon sterline yakın kaynak aktarıldığı belirtilmiştir (Daily Mail Online, 2020). Madrid Belediyesi tarafından salgınla mücadele kapsamında yaşlıların evde kalmalarını kolaylaştırmak ve ihtiyaçlarını karşılamak adına sosyal medya aracı olan "twitter" üzerinden mahalle dayanışma kampanyası düzenlemiştir. Kampanyanın amacı, Madrid'de yaşayan vatandaşların, salgınla mücadele döneminde yardıma ihtiyaç duyan ve evde kalması gereken yaşlılara gönüllü yardım etmesini sağlamaktır. Yardımların kapsamını; günlük ev işleri, yaşlılara yönelik kişisel bakım, alışveriş ve benzeri yardımlar oluşturmaktadır (Enstitü İstanbul, 2020).

\section{Ĕ̆itim Hizmetleri}

COVID-19'un en çok etkilediği alanlardan bir diğeri ise eğitim sektörüdür. DSÖ'nün yeni tip Koronavirüsü pandemi olarak değerlendirmesinin ardından birçok ülke uzaktan eğitim sistemi üzerinden, eğitim ve öğretim faaliyetlerine devam etmiştir. Bu başlık altında yerel yönetimler tarafından sunulan 
en önemli hizmetlerden birisi San Francisco Belediyesi tarafından geliştirilen ve kentin 25 ayrı noktasına kurulan, yüksek hızlı ve fiber altyapılı modemlerden oluşan 'SuperSpots' uygulamasıdır. Bu uygulama sayesinde uzaktan eğitim alan; ancak yeterli internet altyapısına sahip olmayan öğrenciler için evlerinden erişim sağlayabilecekleri ücretsiz ağ bağlantısı sunulabilmektedir (Kron4, 2020).

\section{Kültür, Sanat ve Psikolojik Destek Hizmetleri}

COVID-19'un sosyal etkileri incelendiğinde hiç şüphesiz en büyük tehdidin hastalığın yarattığı sosyal ve psikolojik etkiler olduğu görülmektedir. Türkiye Psikiyatri Derneği'nin 13 Mart 2020 tarihinde yayımladığ 1 'Koronavirüs Hastalığı Salgını Sırasında Ruh Sağlığı ve Stresle Baş Etme' başlıklı yazısinda COVID-19'un insanlar ve topluluklar üzerinde genel olarak kayg ve korku yaratabileceğine; çocuklar ve gençler üzerinde ise bu durumun daha çok endişeye neden olabileceğine yer verilmiştir. Bu aşamada COVID-19 ile mücadele sürecinde insanlara, moral, kültür, sanat etkinliklerine ve psikolojik ihtiyaçlara destek gibi hizmetlerinin sunulmasının, hastalığın sosyal ve psikolojik etkilerini hafifletmede önemli bir unsur olacağı vurgulanmaktadır (Türkiye Psikiyatri Derneği, 2020).

Kültür, Sanat ve Psikolojik Destek Hizmetleri başlığı altında uluslararası düzlemde en dikkat çeken örneklerden birisi, Avustralya ve ABD'de Austin ve Wyndham Belediye Meclislerinin ortaklaşa geliştirdikleri bir proje olan 'Online Community Hubs' platformudur. Dijital bir platform, olan bu yapı, cep telefonuna yüklenen bir uygulama üzerinden çalışmaktadır. Bu platform sayesinde Austin ve Wyndham'da yaşayanlar, her türlü çevrimiçi etkinlikten haberdar olabilmekte, etkinliklere ücretsiz katılım sağlayabilmekte, birbirleri ile iletişim kurarak, sosyal ihtiyaçlarını karşılayabilmektedirler (Wyndhamcity, 2020). Benzer şekilde çocukların evlerinde geçirdikleri süreyi daha eğlenceli ve verimli hale getirebilmek adına Barselona Belediyesi tarafından "Sevgili Günlük" isimli bir internet sitesi hazırlanmıştır. Çocuklar evde kaldıkları süre boyunca şiirlerini, resimlerini, yaptıkları her türlü aktiviteyi internet sitesi üzerinden paylaşabilmektedirler (Barcelona.Cat, 2020). Paris Belediyesi Tiyatrosu ise belediyeye ait olan bir internet sitesi üzerinden düzenli aralıklarla canlı yayınlar yapmaktadır. Yine belediye, karantina nedeniyle evde kalanlar için internet ortamında egzersiz ve spor ile ilgili videolar hazırlamış ve paylaşmıştır (My Paris, 2020). Roma'da sivil toplum ve Roma Belediyesi öncülüğünde kurulan bir dayanışma ağı üzerinden toplum- 
dan izole olarak yaşayan yaşlıların alışveriş ve diğer ihtiyaçları gönüllü gençler tarafından karşılanmakta ve yaşlıların psikolojik durumları süreç boyunca takip edilerek, destek mekanizmaları kurulmaktadır (Bayraktar, 2020)

\section{Sağlık Hizmetlerine Destek}

COVID 19'un etkileri en çok sağlık sektörünü etkilemektedir. Ecza tedariklerinin bozulmasından, çalışanların sağlığına; en küçük bir hatanın felaketlere dönüşebilecek olmasından, halka karşı büyük sorumluluk taşımasına kadar birçok operasyonel risk taşıyan bu sektör, bu aşamada kurtarıcı bir rol üstlenmektedir. Uluslararası şehir örnekleri incelendiğinde salgınla mücadele kapsamında sağlık sektörünün ayakta kalmasına yönelik yerel yönetimlerin de büyük katkıları olduğu dikkat çekmektedir. Örneğin Roma Belediyesi, salgınla mücadele kapsamında 100 adet belediye aracını, sağlık personeli için tahsis ederek ulaşım desteği sağlamaktadır (Enstitü İstanbul, 2020). Paris Belediyesi ise kendi bünyesinde sağlık personeli için maske üretimi yaparak, ücretsiz maske dağıtımı yapmaktadır (My Paris, 2020). Moskova Belediyesi ise kent metrosunun girişlerinde, vatandaşların ateşlerinin ölçüldüğü ekipmanların kurulumunu gerçekleştirerek; yolcuların ateşlerinin ölçülmesi işlevini yürütmektedir (Official website of the Mayor of Moscow, 2020).

Yukarıda uluslararası örnekler üzerinden yapılan araştırmalar sonucunda yerel yönetimlerin, COVID-19 ile mücadele sürecinin önemli bir parçası olduğu dikkat çekmektedir. Yerel yönetimlerin, sağlıktan, eğitime, sosyal yardımdan, kültür, sanat faaliyetlerinin sürdürülmesine kadar salgınla mücadelede önemli bir rol üstlendiği gözlemlenmektedir.

\section{COVID-19 Salgını ile Mücadelede Türkiye'de Yerel Yönetimler}

Uluslararası şehir örneklerinde görüldügü gibi Türkiye'de de pandemi ile mücadele sürecinde yerel yönetimler önemli sorumluluklar üstlenmiştir. Bu dönemde yasal düzenlemelerin kendilerine vermiş olduğu yetkiler çerçevesinde Türkiye'de birçok belediye, yerel ihtiyaçlarını ve kaynaklarını gözeterek farklılaşan ve benzerleşen pandemi ile mücadele yöntemlerini hayata geçirmiş, bazı belediyeler de yenilikçi uygulamaları ile sıklıkla gündeme gelmişlerdir. Dolayısıyla bu dönemde yerel yönetimlerin sınırlı kaynaklarına rağmen hızlı aksiyon alarak başarılı uygulamalara imza attıklarını söylemek yanlış olmayacaktır (Kap, 2020b).

Çalışmanın bu kısmında COVID-19 ile mücadele sürecinde Türkiye örneği üzerinden 30 büyükşehir belediyesi incelenmiştir. Çalışma çerçevesinde 30 büyükşehir belediyesinin, internet siteleri ve dijital kaynakları taranmış ve 
bu alana yönelik yürüttükleri hizmetler derlenmiştir. Yapılan araştırmalara göre pandemi ile mücadele kapsamında Türkiye'de yerel yönetimlerin hizmetlerini, belirli başıklar altında sundukları gözlemlenmiştir. Aşağıda örnek belediyeler üzerinden de tartışılan bu başlıklar şöyledir: (1) Kamuoyunu bilgilendirme ve farkındalık artırma faaliyetlerini yürütmek, (2) Düzenli aralıklarla dezenfekte ve temizlik çalışmalarını yapmak, (3) Yerli maske üretimi ve dağıtımı yapmak, (4) Sağlık hizmetlerine yönelik destek sunmak, (5) Sosyal yardım ve destek hizmetlerini yürütmek, (6) Alınan tedbir ve kısıtlamalara ilişkin denetim çalışmalarını yürütmek, (7) Kültür, sanat, spor ve psikolojik destek hizmetleri sunmak ve (8) Diğer hizmetlerden oluşmaktadır. Çalışma kapsamında "Diğer" hizmetler başlı̆̆ı altında İstanbul, İzmir, Ankara gibi büyükşehir belediyeleri, diğer belediyelerden farklılaşan hizmet alanlarıyla ön plana çıkmaktadır. Bu başlık altında farklılaşan hizmetler örnek belediyeler üzerinden tartışılmıştır. Çalışma kapsamında ayrıca ilgili hizmet başlıkları altında merkezi idarenin, yerel yönetimlerin süreçteki bazı eylem ve faaliyetlerine yönelik kontrol ve müdahalesine yönelik bulgular tespit edilmiş ve bulgulara da ilgili hizmet alanları başlığı altında da yer verilmiştir.

Tablo 1. Çalışma kapsamında araştırılan büyükşehir belediyeleri

\begin{tabular}{lllll}
\hline \multicolumn{2}{l}{ Büyükşehir belediyeleri listesi } & & & \\
\hline Adana & Denizli & İstanbul & Malatya & Sakarya \\
\hline Ankara & Diyarbakır & İzmir & Manisa & Samsun \\
\hline Antalya & Erzurum & Kahramanmaraş & Mardin & Şanlıurfa \\
\hline Aydın & Eskişehir & Kayseri & Mersin & Tekirdağ \\
\hline Balıkesir & Gaziantep & Kocaeli & Muğla & Trabzon \\
\hline Bursa & Hatay & Konya & Ordu & Van \\
\hline
\end{tabular}

\section{Kamuoyunu Bilgilendirme ve Farkındalık Artırma Faaliyetlerini Yürütmek}

Türkiye'de COVID-19'dan korunma önlemlerini, sınırlılıkları, genel önlemleri kamuoyu ile paylaşmak hem merkezi hükümet hem de yerel yönetimler tarafından yerine getirilmektedir. Yerel yönetimler tarafından yapılan kamuoyunu bilgilendirme faaliyetlerini 30 büyükşehir belediyesinin tamamı yerine getirmektedir. Büyükşehir belediyelerinin tamamı, internet siteleri ve sosyal medya hesapları üzerinden kent genelinde alınan önlemleri ve COVID-19 ile mücadele kapsamında alınması gereken tedbirleri paylaşmaktadırlar. Bu hizmet alanları dışında belediyeler tarafından yürütülen diğer kamuoyunu bilgilendirme faaliyetleri ağırlıklı olarak; belediyeler tarafından hazırlanan tanıtıcı posterler, toplu taşımalarda, okullarda ve iş yerlerinde ger- 
çekleştirilen farkındalık artırma kampanyaları üzerinden gerçekleştirilmektedir. Aşağıda kamuoyunu bilgilendirme kapsamında bazı büyükşehir belediye örneklerine yer verilmiştir:

- Ankara Büyükşehir Belediyesi, kendi internet sitesi üzerinden dünyada COVID-19 önlemlerinin nasıl paylaşıldığını aktarmaktadır. Yine Belediye, Sağlık Bakanlığı'nın COVID-19 ile ilgili temel bilgilendirme metinlerini ve kentteki genel önlemlere yönelik duyurularını, toplu taşıma ve metro araçlarında bulunan ekranlarda yayımlamakta ve paylaşmaktadır (T.C. Ankara Büyükşehir Belediyesi, 2020).

- Konya Büyükşehir Belediyesi, "Koronavirüsten Nasıl Korunulur?" içerikli broşürler üzerinden yurttaşların salgından ve diğer virüslerden nasıl korunması gerektiği konusunda bilgilendirme çalışmaları yapmaktadır. Bu broşürler, toplu taşımayı kullanan vatandaşlar ile okullardaki öğrencilere dağıtılmaktadır (Konya Su ve Kanalizasyon İdaresi Genel Müdürlüğü, 2020).

- Antalya Büyükşehir Belediyesi, salgın kapsamında ülke genelinde yürütülen 'Evde Kal Türkiye' kampanyasına destek vermek ve salgın hakkında kamuoyunu bilgilendirme ve farkındalık artırma sürecinde yer almak için il sınırları içerisinde yer alan tüm trafik ışıklarında düzenlemeye gitmiştir. Bu kapsamda trafik ışıklarında sürücülere yeşil ışık yandığında 'Eve Git', kırmızı ışık yandığında ise 'Evde Kal' mesajı verilerek, farkındalık yaratılmaya çalışılmıştır (Türkiye Belediyeler Birliği, 2020a).

- Mersin Büyükşehir Belediyesi, evde kal çağrısı kapsamında belediye personeli başta olmak üzere COVID-19 ve çocuk psikolojisi kapsamında "Ebeveyn Farkındalık Eğitimleri" vermiştir (Mersin Büyükşehir Belediyesi, 2020).

Bir önceki kısımda uluslararası yerel yönetim örnekleri incelendiğinde, yerel yönetimlerin hizmet sunmakla yükümlü olduğu yerlerde COVID-19 salgınına ilişkin alınan tedbir ve kısıtlamalardan; günlük vaka sayılarına ve ölüm oranlarına kadar her türlü bilginin bizzat kendileri tarafindan kamuoyu ile paylaşıldığını göstermektedir. Ancak Türkiye'de salgının gidişatına ilişkin bu bilgilendirme Sağlık Bakanlığı; alınan tedbir ve kısıtlamalar ise İçişleri Bakanlığ ya da Cumhurbaşkanlığı tarafından kamuoyu ile paylaşılmaktadır. Yukarıda da görüldüğü gibi bu noktada yerel yönetimler sadece, salgından korunma yöntemleri, belediyeler tarafından alınan temel önlemler ve farkındalık artırma kampanyaları üzerinden kamuoyuna bilgilendirme faaliyetlerini yapabilmektedirler (Bayraktar, 2020). 


\section{Düzenli Aralıklarla Dezenfekte Ve Temizlik Çalışmaların Yürütmek}

COVID-19, virüsü taşıyan kişilerin solunum yollarından çıkan damlacıklar yoluyla bulaşmaktadır. Dolayısıyla süreç içerisinde çok kullanıcılı mekânların ve temas edilen yüzeylerin temizliğine dikkat edilmesi, salgının bulaşma riskinin azalmasında etkili yöntemlerden birisidir (Türkiye Bilimler Akademisi, 2020). Bu nedenle kent genelinde yüzeylerin ve mekânların hijyenlerinin sağlanmasına yönelik uygulamalar ve dezenfeksiyon çalışmaları, yerel yönetimlerin COVID-19 ile mücadele kapsamında aldığı en temel önlemlerin başında gelmektedir. Kent içi dezenfekte ve temizlik çalışmalarını 30 büyükşehir belediyesinin tamamı yerine getirmektedir. Bunun yanında büyükşehir belediyeleri tarafından toplu taşıma araçlarının, parkların, bahçelerin, meydanların, meyve ve sebze hallerinin temizliği ve ilaçlanması yapılmaktadır. Aşağıda büyükş̧ehir belediyeleri tarafından bu başlık altında sunulan hizmetlere ilişkin örnekler şöyledir:

- Şanlıurfa Büyükşehir Belediyesi, il sınırlarında günde 2 bine yakın toplu taşıma ve vatandaşların özel araçlarını dezenfekte etmektedir. Ayrıca belediye, kent merkezinde ve bazı ilçelerde dezenfekte istasyonları kurmuş ve çalışmalarını bu istasyonlardan yürütmektedir (Şanlıurfa Büyükşehir Belediyesi, 2020).

- Eskişehir Büyükşehir Belediyesi, otogar, Katı Atık Enerji Üretim ve Dönüşüm Tesisi gibi kapalı alanlarda, tramvaylar ve otobüsler, duraklar ve bilet gişelerinde her gün dezenfeksiyon çalışmalarını yürütmektedir. Ayrıca COVID-19 ile mücadele kapsamında belediye tarafından kent içi mobilyalar düzenli olarak ilaçlanmaktadır (Eskişehir Büyükşehir Belediyesi, 2020).

- Aydın Büyüksşehir Belediyesi, kent içi ilaçlama ve temizlik faaliyetlerinin yanında hijyen ekipleri tarafından meyve-sebze dağitımı yapılan hallerin dezenfeksiyon işlemlerini yapmaktadır (Aydın Büyükşehir Belediyesi, 2020).

- Kahramanmaraş Büyükşehir Belediyesi, vatandaşların yoğun olarak kullandığı çarşı, meydan ve piknik alanlarında ilaçlama ve dezenfekte çalışmalarını sürdürmektedir (Kahramanmaraş Büyükşehir Belediyesi, 2020).

- Samsun Büyükşehir Belediyesi, pandemi hastaneleri başta olmak üzere toplam 565 sözleşmeli sağlık kuruluşundan tıbbi atıkları toplamakta ve bu atıkları belediye bünyesindeki Tıbbi Atık Sterilizasyon Tesisi'nde zararsız evsel atığa dönüştürmektedir (Samsun Büyükşehir Belediyesi, 2020).

- Manisa Büyükşehir Belediyesi, kent merkezindeki tüm camileri, park ve bahçeler, çocuk oyun alanları ve otobüs duraklarında ilaçlama ve dezenfeksiyon çalışmalarını yürütmektedir (Türkiye Belediyeler Birliği, 2020b). 


\section{Yerli Maske Üretimi Ve Dağıtımı Yapmak}

COVID-19'un bulaşma riskini azaltmak için 5 Haziran 2020 tarihinde DSÖ tarafından maske kullanımına ilişkin öneri kılavuzu yayınlanmışır. Bu kılavuzda temel olarak maske kullanımının önemi ve halka açık alanlarda maske takılmasının teşvik edilmesi tavsiye edilmektedir (World Health Organization, 2020). Türkiye'de de 30 büyükşehir belediyesi için 3 Nisan 2020 tarihinde İçişleri Bakanlığı tarafından yayımlanan genelge kapsamında maske takma zorunluluğu getirilmiştir ${ }^{3}$ (T.C. İçişleri Bakanlığı, 2020a). Nisan tarihinde çıkartılan genelge sonrasında 30 büyükşehir belediyesinin neredeyse tamamının koordinasyonunda yerli maske üretimi ve üretilen maskelerin dağıtımı yapılmıştır. Büyükşehir belediyeleri tarafından bu başlık altında sunulan hizmetlere ilişkin örnekler şöyledir:

- Malatya Büyükşehir Belediyesi koordinesinde il genelinde 15 büyük tekstil fabrikası, maske üretimi yapmaktadır. Üretilen maskeler Malatya Büyükşehir Belediyesi ve Malatya Su ve Kanalizasyon İdaresi Genel Müdürlüğü personelleri tarafından vatandaşlara dağıtılmaktadır (Malatya Büyükşehir Belediyesi, 2020).

- İzmir Büyükşehir Belediyesi, Meslek Fabrikası kursları bünyesinde günde 60 bin maske üretimi yapmaktadır. Üretilen maskelerin dağıtımı belediye personeli tarafından gerçekleştirilmektedir. Ayrıca metro istasyonları önlerinde yer alan maskematik makinaları da ücretsiz maske dağıtımına destek vermektedir (İzmir Büyükşehir Belediyesi, 2020b).

\section{Sağlık Hizmetlerine Yönelik Destek Sunmak}

Salgınla mücadele kapsamında sağlık sektörünün ayakta kalmasına yönelik Türkiye'de de yerel yönetimlerin büyük katkıları olduğu dikkat çekmektedir. 24 Mart 2020 tarihinde 31078 sayılı Resmi Gazete' de yayımlanarak yürürlüğe giren Cumhurbaşkanı Kararı ile sağlık çalışanlarına ücretsiz ulaşım ve konaklama ile ilgili düzenleme yapılmıştır. Bu düzenleme kapsamında sağlık çalışanlarının ilgili belediyenin sunduğu toplu taşıma hizmetlerinden ücretsiz yararlanmasının yolu açılmıştır (T.C. Sağlık Bakanlığı, 2020). Bu kararla beraber büyükşehir belediyelerinin tamamı sağlık çalışanlarına ücretsiz ulaşım desteği sunmaya başlamışlardır. Bu hizmetin yanı sıra bazı belediyeler, hastanelere hasta nakil hizmeti sunmak, sağlık destek çağrı merkezi kurmak, salgınla mücadele sürecini başarıyla tamamlayan ve hastaneden ta-

\footnotetext{
${ }^{3} 8$ Eylül 2020 tarihinde çıkarılan yeni bir genelge ile de 81 il genelinde bulaş riskini azaltabilmek adına maske takma zorunluluğu getirilmiştir (T.C. İçişleri Bakanlığı, 2020a).
} 
burcu olacak vatandaşlara servis desteği sunmak gibi hizmetleri de sağlayarak, sağlik hizmetlerine destek olmaktadırlar. Büyükşehir belediyeleri tarafından bu başlık altında sunulan hizmetlere ilişkin örnekler şöyledir:

- Gaziantep Büyükşehir Belediyesi ve Gaziantep Valiliği işbirliğinde, yeni COVID-19 Sağlık Destek Hattı Çağrı Merkezi kurulmuştur. Bu merkez, Koronavirüs şüphesi olan vatandaşların kayıtlarını alarak, İl Sağlık Müdürlüğü ile koordineli olarak çalışmayı hedeflemektedir. Yapı, bu amaçla kurulan Türkiye'deki ilk merkez olma özelliği taşımaktadır (Gaziantep Büyükşehir Belediyesi, 2020).

- Van Büyükşehir Belediyesi, bünyesindeki araçlarını hasta nakil aracı olarak tasarlayıp, evde bakıma muhtaç ve hastaneye gitmesi gereken vatandaşları hastaneye taşıma görevi üstlenmektedir (Van Büyükşehir Belediyesi, 2020).

- Sakarya Büyükşehir Belediyesi, salginla mücadele sürecini başarıyla tamamlayan ve hastaneden taburcu olacak vatandaşlara servis desteği sunmaktadır (Medyabar, 2020).

- İstanbul Büyükşehir Belediyesi'nin bünyesinde bulunan 35 adet ambulans, hasta nakil hizmeti sunmak amacıyla Koronavirüse karşı özel olarak donatılmıştır (İstanbul Büyükşehir Belediyesi, 2020b)

\section{Sosyal Yardım Ve Destek Hizmetlerini Yürütmek}

COVID-19 ile mücadele kapsamında Türkiye'de yerel yönetimler sosyal yardım ve destek hizmetleri bağlamında önemli roller üstlenmişlerdir. Yukarıda da vurgulandığı gibi çocuktan, gence; engelliden, kadına; yaşlıdan dar gelirliye kadar kapsamlı bir gruba yönelik sosyal içerikli faaliyetleri kapsayan sosyal yardım hizmetleri, geniş bir hizmet alanına sahiptir. Uluslararası örneklere benzer şekilde Türkiye' de de pandemi ile mücadele döneminde büyükşehir belediyelerinin tamamının, bu kategori altında birçok hizmeti yerine getirdiği görülmektedir. Yürütülen bu hizmetler genel olarak aşağıdaki gibidir:

- Maddi yardım desteği,

- Gida ve temizlik paketi desteği,

- Sıcak yemek dağıtımı,

- Alışveriş desteği,

- Evde bakım desteği,

- Evsiz ve ihtiyaç sahiplerine yönelik barınma desteği.

Yukarıda belirtilen hizmetlerin yanı sıra; salgınla mücadele döneminde, sosyal yardım hizmetleri kapsamında vatandaşlara kolaylık sağlamak üzere belediyeler özelinde yeni bir düzenleme yapılmıştır. "Yeni Koronavirüs (COVID-19) Salgınının Ekonomik Ve Sosyal Hayata Etkilerinin Azaltılması 
Hakkında Kanun İle Bazı Kanunlarda Değişiklik Yapılmasına Dair Kanun" kapsamında yapılan bu düzenleme, yerel yönetimlere mülkiyetlerinde olan taşınmazlar için alacaklarının belirli bir süre için ertelemesini getirmektedir (2020). Bu bağlamda bazı belediyeler (Ankara, İstanbul, İzmir, Manisa, Adana, Antalya, Mersin Büyükşehir Belediyeleri) kira borçlarını, su faturalarını ve diğer alacaklarını belli bir süreliğine erteleme yetkisi ile vatandaşa özellikle de esnafa- kolaylık sağlamaktadırlar. Yine bu dönemde kırsal kalkınmayı desteklemek, tarım ve gıda sektörünün zararlarını en aza indirebilmek adına bazı büyükşehir belediyeleri (Ankara, İstanbul, İzmir, Gaziantep, Adana, Antalya, Balıkesir, Aydın, Kocaeli, Samsun, Büyükşehir Belediyeleri) tarafından üretici ve çiftçilere ayni ve nakdi yardımlar yapılarak, destek verilmektedir. Salgınla mücadele kapsamında sokak hayvanlarının beslenmesi de neredeyse bütün büyükşehir belediyelerinin gündeminde yer alan konuların başında gelmektedir. Bu dönemde yine bazı büyükşsehir belediyeleri, sokak hayvanları için yem ve mama desteği sağlamaktadır. Büyükssehir belediyeleri tarafından bu başlık altında sunulan hizmetlere ilişkin örnekler şöyledir:

- Trabzon Büyükşehir Belediyesi, ihtiyaç sahiplerine (işini kaybedenler, ücretsiz izne çıkarılanlar ve ekonomik sıkıntı çekenlere) temel gıda paketleri, temizlik paketleri destekleri sağlamıştır. Ayrıca belediye tarafından yaşlı, hasta vatandaşlara ve muhtaç ailelere sıcak yemek dağıtımı; dar gelirli ailelere de ihtiyaçlarını karşılayabilmeleri için alışveriş desteği sağlanmıştır (Trabzon Büyükşehir Belediyesi, 2020).

- Muğla Büyükşehir Belediyesi 438 ihtiyaç sahibi aileye (yoksul, kimsesiz, evsiz, engelli ve ihtiyaç sahibi vatandaşlar) ulaşarak, pandemi ile mücadele kapsamında 335 bin 610 TL maddi yardım yapmıştır (Muğla Büyükşehir Belediyesi, 2020).

- Kocaeli Büyükşehir Belediyesi tarafından evsiz ve ihtiyaç sahibi ailelerinin, Büyükşehir Belediyesi'nin Barınma, Konaklama ve Sosyal Yardım Merkezinde barınma ihtiyaçları karşılanmaktadır. Ayrıca Barınma Merkezi'nde kalan vatandaşların düzenli olarak sağlık kontrolleri yapılmaktadır (Kocaeli Büyükşehir Belediyesi , 2020).

- Ankara Büyükşehir Belediyesi salgınla mücadele tedbirleri kapsamında, büyükşehir belediyesi kiracıları için kira alımını belli bir süre için erteleyerek, esnafın yanında olduğunu belirtmiştir (CNNTÜRK, 2020).

- Ankara Büyükşehir Belediyesi evlere temizlik desteğine giden kadınları, İstanbul Büyükşehir Belediyesi ise sokak müzisyenlerini sosyal yardım grupları arasında tanımlamış; onlara virüs salgını nedeniyle yaşadıkları mağduriyetleri gidermek adına gıda ve nakit desteği yardımları yapmışlardır (Yeni Haber, 2020). 
- Adana Büyükşehir Belediyesi tarafından il sınırları içerisinde yaşayan çiftçilere ve balıkçılara, dekar başı ve tekne başına nakdi hibe yardımı yapılmıştır (Adana Büyükşehir Belediyesi, 2020).

- Balıkesir Büyükşehir Belediyesi tarafından belediye arazisinde yerli üretim yapılmaya başlanmıştır. Ayrıca üreticilerin tohum bedellerinin yüzde 50'sinin belediye eliyle karşılanması kararı alınmıştır (Balıkesir Büyükşehir Belediyesi, 2020).

- Kayseri Büyükşehir Belediyesi, salgınla mücadele kapsamında sokak hayvanlarına ve ilçelerde yaşayan sahipsiz hayvanlara yem ve mama desteği sunmaktadır (Kayseri Büyükşehir Belediyesi, 2020).

Salgının başlangıç döneminde bazı büyükşehir belediyeleri (Ankara, İstanbul, Gaziantep, Konya) tarafından ihtiyaç sahibi vatandaşlara yönelik maddi yardımda bulunmak amacıyla bağış kampanyaları başlatılmıştır. Ancak İçişleri Bakanlığı tarafından kısa bir süre içerisinde duruma müdahale edilmiş, "Yardım Toplama Hususuna İlişkin Kamuoyu Bilgilendirmesi” yapılmıştır. Bu bilgilendirmeye göre belediyeler tarafından toplanan maddi desteklerin bağıştan ziyade; yardım kampanyası kapsamında değerlendirilmesi gerektiği vurgulanmış, Yardım Toplama Kanunu'nun 6. maddesine istinaden de belediyelerin izinsiz yardım kampanyaları toplamasının hukuka uygun olmadığı belirtilmiştir. Ardından belediyelerin para topladıkları hesaplara merkezi idare tarafından bloke konulmuş ve süreç durdurulmuştur (T.C. İçişleri Bakanlığı, 2020c). Ankara, İstanbul, İzmir gibi bazı büyükş̧ehir belediyeleri ise faaliyetlerinin yardım kampanyasından öte bağış kampanyası kapsamında değerlendirilmesi gerektiğini ve bu durumun da yerel yönetimler kanunlarına aykırılık teşkil etmediğini belirtmişlerdir. 2 tarafta da uzlaşı sağlanamamış, merkezi idare, yardımların tek bir kaynakta toplanması kapsamında "Biz bize yeteriz Türkiyem" kampanyasını başlatmıştır. Merkezi idare tarafından gelen yasaklamalara rağmen önce İstanbul Büyükşehir Belediyesi ardından da diğer belediyeler (Ankara, İzmir, Antalya, Aydın, Hatay) tarafından başlatılan "Askıda Fatura" uygulaması dikkat çekmektedir. Bu uygulama ile salgın dönemi boyunca su ve doğalgaz faturaların ödeyemeyen ihtiyaç sahibi ailelerin faturalarının ödenmesi mümkün hale gelmiştir (İstanbul Büyükşshir Belediyesi, 2020a). Yine aynı dönemde Ankara Büyükşehir Belediyesi ise 'Su Ver', 'Bilet Ver' ve 'El Ver' sloganı ile birlikte, “Dayanışma için 6 milyon tek yürek", "Veresiye Defteri Kapatma”, "Ifftar Ver", “6 Milyon Tek Yürek Bayram Etsin" kampanyaları başlatılmıştır. Kampanyalar kapsamında toplamda 28 milyon 399 bin 523 TL maddi yardım toplanmış ve ihtiyaç sahiplerine ulaştırılmıştır (Ankara Büyükşehir Belediyesi, 2020a). 
Salgınla mücadele döneminde merkezi idarenin sürecin odağında olma ısrarının bir başka örneği ise ihtiyaç sahiplerine yönelik yardım ve desteklerin valilikler bünyesinde kurulan Vefa Sosyal Destek Grupları tarafından yerine getirilmesini sağlamaktır. Yine merkezi idarenin, salgınla mücadele sürecinde alınan sokağa çıkma yasakları tedbirleri kapsamında, belediyeler tarafından ekmek dağıtımı gibi temel hizmetlerin yerine getirilmesine yönelik eleştiri ve engelleme faaliyetleri de, merkezi idarenin yerel yönetimlerin eylem ve işlemlerine yönelik müdahalesi olarak değerlendirilebilir (Bayraktar, 2020).

\section{Alınan Tedbir Ve Kısıtlamalara İlişkin Denetim Çalışmaların Yürütmek}

COVID-19 salgını döneminde alınan tedbir ve kısıtlamalara uyulup uyulmadığına yönelik yapılan denetim çalışmalarının önemli bir kısmı büyükşehir belediyeleri tarafından yerine getirilmiştir. 30 büyükşehir belediyesinin tamaminda; hijyen, sosyal mesafe, maske takma kuralları, COVID-19 salginı kapsamında herhangi bir risk taşıyıp taşımadığın güvenli şekilde paylaşan Hayat Eve Sığar (HES) kodu denetimleri gibi tüm denetim faaliyetleri, zabita birimlerince düzenli bir şekilde yürütülmektedir. Bu kapsamda büyükşehir belediyeleri tarafından bu başlık altında sunulan hizmetlere ilişkin örnekler şöyledir:

- Mardin Büyükşehir Belediyesi zabıta ekipleri tarafından İçişleri Bakanlığı tarafından çıkarılan ilgili genelge uyarınca şehirlerarası otobüs terminalinde HES kodu denetimi gerçekleştirilmektedir (Mardin Büyükşehir Belediyesi, 2020).

- Erzurum Büyükşehir Belediyesi zabıta birimi, sosyal mesafe kuralları ile maske ve eldiven kullanımı denetimlerini, marketler başta olmak üzere gıda ürünlerinin satışının yapıldığı tüm işletmelerde düzenli aralıklarla yapmaktadır (Erzurum Büyükşehir Belediyesi, 2020).

- Tekirdağ Büyükşehir Belediyesi zabita ekipleri, kent genelinde toplu taşıma araçları ile ticari taksilerde sosyal mesafe, maske kullanımı ve hijyen kurallarına uyulup uyulmadığına ilişkin denetimlerini düzenli aralıklarla gerçekleştirmektedir (Tekirdağ Büyükşehir Belediyesi, 2020).

- Hatay Büyükşehir Belediyesi zabita birimi tarafından kent genelindeki cadde ve sokaklarda hijyen, sosyal mesafe ve maske kurallarına yönelik denetimlerini düzenli aralıklarla yerine getirmektedir (Hatay Büyükşehir Belediyesi, 2020). 


\section{Kültür, Sanat, Spor Ve Psikolojik Destek Hizmetleri}

Pandemi ile mücadelede Türkiye'de birçok büyükşehir belediyesi "Kültür, Sanat, Spor Ve Psikolojik Destek Hizmetleri" kapsamında hizmetler sunmuşlardır. Bu başlık altında büyükşehir belediyeleri, spor müsabakaları, öğrencilere yönelik eğitsel destek, fotoğraf yarışmaları, çevrim içi konserler, seyyar müzik, eğlence programları, psikolojik danışmanlık ve destek hizmetleri sunmuşlardır. Büyükşehir belediyeleri tarafından bu başlık altında sunulan hizmetlere ilişkin örnekler şöyledir:

- Ordu Büyükşehir Belediyesi Gençlik ve Spor Hizmetleri Dairesi Başkanlığı işbirliğinde satranç sporcularına moral ve destek sağlamak amaciyla "Ulusal Evde Kal Online Yıldırım Satranç Turnuvası" düzenlemiş ve sosyal medya araçları üzerinden canlı olarak turnuvayı izleme imkanı sunmuştur (Türkiye Belediyeler Birliği, 2020d).

- Bursa Büyükşehir Belediyesi Kültür ve Sosyal İşler Daire Başkanlığı Orkestra Şube Müdürlüğü sanatçıları tarafından hafta içi her gün belediyenin kendi internet sayfası üzerinden canlı yayınlarla evde kalanlar için konserler vermektedir (Bursa Büyükşehir Belediyesi, 2020).

- Gaziantep Büyükşehir Belediyesi salgınla mücadele kapsamında vatandaşa moral vermek amacıyla belediye bünyesindeki spor hocaları eşliğinde vatandaşlara balkonlarından spor yaptırmaktadır (Sivil Sayfalar, 2020a).

- Denizli Büyükşehir Belediyesi, sokağa çıma yasakları nedeniyle 23 Nisan Ulusal Egemenlik ve Çocuk Bayramı kapsamında belediyenin bando takımı, cadde ve sokaklarda marşlar çalarak, vatandaşlara bayram heyecanı yaşatmıştır (Denizli Büyükşehir Belediyesi, 2020).

- Diyarbakır Büyükşehir Belediyesi, 20 yaş altı ve 65 yaş üstü vatandaşlara yönelik "Hayat Eve Sığar" temalı ödüllü fotoğraf yarışması düzenlemiş ve kendi internet sayfası üzerinden yarışmaya yönelik tüm bilgileri paylaşmıştır (Diyarbakır Büyükşehir Belediyesi, 2020).

- İstanbul Büyükşehir Belediyesi tarafından salgın döneminde İstanbullu vatandaşların kaygı düzeylerini dengelemek, endişelerini gidermek ve psikolojilerini güçlü tutmak amacıyla "Psikolojik Danışmanlık Hattı" hizmete açılmıştır (İstanbul Büyükşehir Belediyesi, 2020c).

- Mardin Büyükşehir Belediyesi, COVID-19 tedbirleri kapsaminda evinde kalan ilköğretim öğrencilerine "100 temel eserden seçmeler" kitaplarını hediye ederek, hem eğitsel hem de moral desteği sunmuştur (Türkiye Belediyeler Birliği, 2020c).

- Kayseri Büyükşehir Belediyesi tarafından günde 2 defa belediyenin internet sitesinden canlı olarak spor desteği verilmektedir (Hürriyet, 2020). 


\section{Diğer Hizmetler}

Salgınla mücadele kapsamında yukarıda belirtilen ve yerel yönetimler tarafından sunulan hizmetlerin dışında bazı belediyeler süreçte sunmuş oldukları farklı hizmet alanları ile gündeme gelmiştir. İstanbul, Ankara, İzmir, Bursa gibi büyükşehir belediyeleri yukarıda belirtilen hizmetlerin yanı sıra salgınla mücadele kapsamında; (1) eylem planı hazırlamak, (2) bilim kurulları kurarak, sürece yönelik mücadele yöntemleri geliştirmek, (3) katılım mekanizmalarını canlandırarak sosyo-kültürel ilişkileri geliştirmek, (4) eğitim hizmetlerine destek vermek gibi diğer belediyelerden farklılaşan hizmet alanlarıyla ön plana çıkmaktadır. Aşağıda bu başlık altında büyükşehir belediye örneklerine yer verilmiştir:

- İzmir Büyükşehir Belediyesi tarafından Haziran ayında "COVID-19 Dirençlilik Eylem Planı" hazırlanmıştır. Bu plan İzmir ilinde, (1) pandemi benzeri kriz durumlarında geçmişten bugüne devam eden önleyici hizmetler, (2) pandemi ile mücadele kapsamında "Kriz Belediyeciliği" yaklaşımı ile bugün yürütülen çalışmalar ve (3) pandemi sonrasında yapılacak çalışmalar çerçevesinde izleme ve adaptasyon sürecini içeren 3 temel başlık göz önünde bulundurularak hazırlanmıştır (İzmir Büyükşehir Belediyesi, 2020a). Geçmiş ve gelecek adımları içeren bu eylem planı, İzmir Büyüksşehir Belediyesi için gerçek anlamda bir yol haritası niteliğindedir. Ayrıca İzmir Büyükşehir Belediyesi, bu süreçte yeni bir yönerge çlkararak; sivil toplum örgütlerinden, üniversitelere, sağlık birimlerinden merkezi yönetimin ilgili birim temsilcilerine kadar geniş kapsamlı 3 yeni kurul kurmuş ("Kriz Yönetim Üst Kurulu”, "Kriz Yönetim İcra Kurulu" ve "Bilim Kurulu") ve salgınla mücadele sürecinde yönetişim mekanizmalarını aktif hale getirmiştir (Sivil Sayfalar, 2020a).

- İzmir Büyükşehir Belediyesi ile benzer bir eylem planı Bursa Büyükşehir Belediyesi tarafından yayımlanmışır Bu eylem planı da 1 Haziran-30 Eylül tarihleri arasında belediyenin kontrollü normalleşme süreciyle ilgili hizmet alanlarını, alınacak önlem, risk ve tedbirleri içermektedir.

- Ankara Büyükşehir Belediyesi tarafindan kurulan, uluslararası düzeyde 43 başkent belediyesini bünyesinde barındıran 'COVID-19'a Karşı Başkentliler Dayanışması' adlı bir platform da salgınla mücadele kapsamında geliştirilen ve dikkat çeken çalışmalardan bir diğerini oluşturmaktadır. Platform, "koronavirüs salgını ile mücadelede diğer dünya başkentlerinin bu süreçte kazandıkları deneyim ve birikimlerini tek bir havuzda bir araya" getirmeyi hedeflemektedir (Cumhuriyet Gazetesi, 2020). Bu dayanışma ağı üzerinden COVID-19 salgınına karşı mücadelede başkent belediyeleri, çevrimiçi platform üzerinden deneyimlerini düzenli aralıklarla paylaşmaktadır (Capital Ini- 
tiatives for COVID-19, 2020). Böyle bir girişim katılım mekanizmalarını canlandırarak sosyo-kültürel ilişkileri geliştirmekte ve pandemi ile mücadele ve sonrasında önemli bir paylaşım ve bilgi ağı oluşturmaktadır.

- İstanbul Büyükşehir Belediyesi, üst düzey yöneticileri, İstanbul İl Sağlık Müdürlüğü, İstanbul Tabip Odası, çeşitli üniversite ve kamu hastanelerinden doktorlar, psikiyatri uzmanları ve konuyla ilgili yetkin personellerden oluşan bir bilim kurulu kurulmuştur Yine benzer şekilde İstanbul Yardımlaşma ve Koordinasyon Merkezi oluşturularak; salgınla mücadele sürecinde eylem ve stratejilerin belirlenmesinde ortak bir akıl yaratılmıştır (İstanbul Büyükşehir Belediyesi, 2020a).

- Uzaktan eğitime destek hizmetleri kapsamında Ankara Büyükşehir Belediyesi tarafından bilgisayarı ya da interneti olmayan ihtiyaç sahibi ailelerin çocuklarının kullanımına, belediye bünyesindeki 869 adet bilgisayar açılmıştır. Ayrıca interneti olmayan kırsal mahallelerdeki öğrencilerin yararlanması amaciyla da Çiçektepe, Esenler, Polatlar mahalleleri başta olmak üzere bazı kırsal mahallelerde fiber altyapı sistemi güçlendirilerek, bu bölgelere internet hizmeti götürülmüsstür (Ankara Büyükşehir Belediyesi, 2020b).

Belediye örnekleri üzerinden yapılan araştırmalar sonucunda Türkiye'de yerel yönetimlerin, COVID-19 ile mücadele sürecinin önemli bir parçası olduğu dikkat çekmektedir. Her ne kadar merkezi idare, salginla mücadele sürecinin odağında yer alma konusunda israrlı olsa da (Bayraktar, 2020); büyükşehir belediyelerinin, sağlıktan, eğitime, sosyal yardımdan, kültür, sanat faaliyetlerinin sürdürülmesine kadar salginla mücadelede önemli bir rol üstlendiği gözlemlenmektedir.

\section{Sonuç ve Genel Değerlendirme}

Dünyayı etkisi altına alan COVID-19'a karşı mücadele sürecinde yerel yönetimlerin, önemli sorumluluklar üstlendiği çalışma kapsamında verilen ulusal ve uluslararası örnekler üzerinden görülmektedir. Süreçle mücadelede yerel yönetimler, hızlı aksiyon alarak başarılı uygulamalara imza atmışlardır (Sivil Sayfalar, 2020b). Özellikle bu dönemde yerel yönetimler, merkezi idarenin hızlı etki gösteremediği, ihtiyaç alanlarına çözüm üreterek önemli bir boşluğu doldurmaktadırlar. Yerel yönetimlerin, COVID-19'un toplum üzerindeki etkilerini ve yerel düzeydeki riskleri hızlı analiz ettiği ve bu noktada da yönlendirici bir konumda olduğu, çalışma kapsamında tespit edilen bir diğer önemli noktadır (Bayraktar, 2020). 
Uluslararası ölçekte yerel yönetimlerin; sağlıktan, eğitime, sosyal yardımdan, kültür, sanat faaliyetlerinin sürdürülmesine kadar salgınla mücadelede önemli bir rol üstlendiği gözlemlenmektedir. Türkiye'de de krizde başarılı bir sınav veren yerel yönetimler tarafından yaratıcı hizmetlerin üretildiği ve sunulduğu görülmektedir. Bu dönemde maske üretiminden, sosyal yardım hizmetlerinin etkinlik alanlarının genişletmesine, dijital platformlar aracılığ ile evde spor, kültür, sanat gibi hizmetlerin yürütülmesinden, üretici ve çiftçilere destek sağlanmasına kadar geniş bir hizmet alanı, büyükşehir belediyeleri tarafından sunulmaktadır. Yine bu dönemde merkezi idarenin COVID-19 ile mücadele sürecinde yerel yönetimlerin eylem ve işlemlerine müdahalesi dikkat çekicidir. Merkezi idarenin bu müdahalesi özellikle kamuoyunu bilgilendirme faaliyetleri, sosyal yardım hizmetlerinin sunumu gibi temel nitelikli hizmet alanlarında gözlemlenmektedir. Ancak salgının seyrinin daha yakından takip edilmesi ve salgın sonucu ortaya çıkan ihtiyaçlara çözüm üretme noktasında kapasite ve imkânlar bakımından merkezi idare ile yarışamasalar dahi, sürece hızlı adapte olma ve reaksiyon geliştirme açısından yerel yönetimlerin çok önemli bir noktada olduğu gözlemlenmektedir (Sivil Sayfalar, 2020b). Kısacası sahip oldukları kaynak sınırlılıkları, merkezi idarenin kontrol ve müdahalelerine rağmen, Türkiye'de yerel yönetimler salgınla mücadele konusunda ortaya çıkan ihtiyaçlara yönelik yerel nitelikli çözümler üreterek, sürece önemli katkılar sağladığı ve bu yönde güçlü çaba harcadığı dikkat çekmektedir.

İçinde yaşadığımız bu dönemle beraber yerel yönetimlerin önemi bir kez daha anlaşılmıştır. Bu ve benzeri kriz dönemlerinde mücadele alanları ve yerel nitelikli ihtiyaçlara çözüm üretme becerileri göz önünde bulundurulduğuna yerel yönetimlerin daha çok güçlendirilmesi, merkezi idare ile yerel yönetimler arasındaki ikili ilişkilerin geliştirilmesi gereklidir. Bu bağlamda merkezi idarenin işsizlik maaşı, borçların ertelenmesi gibi daha genel yardımları ve politikaları merkezi düzeyde yürütmesi; yerel ölçekte ise bu sürecin doğrudan yerel yönetimler aracllı̆̆yla desteklenmesi ve güçlendirmesi gerekmektedir. Yerel yönetimlerin de bu süreci planlarken ve yürütürken sivil toplum örgütleri, üniversiteler ve özel sektörle işbirliği yapması ve onları sürecin içine dahil etmesi gerekmektedir (Sivil Sayfalar, 2020b). Kriz ile mücadele dönemlerinde merkezi hükümetin sosyal devlet ilkesini göz önünde bulundurarak, yerel yönetimlerden gelen talepleri dikkate alması, ortak bir sorumluluk bilinci ile hareket ederek; yerel yönetimlerin görev alanlarına müdahaleden sakınmaları gerekmektedir. Bu da ancak yönetişim mekanizmalarının etkin kılındığı kapsamlı bir salgınla mücadele politikalarının geliştirilmesi ve yürütülmesi ile hayata geçirilebilir. 


\title{
Extended Abstract
}

\section{Overview of the Local Governments in the Process of Combating COVID-19}

\author{
$*$ \\ Asmin Kavas Bilgiç \\ ORCID: 0000-0001-8319-7950
}

Since March 11, 2020, when the new type of coronavirus, also known as Covid-19, was described as a pandemic, the whole world has been alarmed about the fight against the epidemic. Local government units, governments, international institutions, and organizations are looking for ways to combat the epidemic with the solutions they have developed and continue to improve.

Today, 55 percent of the world's population lives in urban areas. This epidemic also shows its effect more intensely in urban areas with high population. The role of local governments, which are authorized to provide the closest service to the citizen at the urban scale, is significant in combating the epidemic. Accordingly, local governments aim to reduce the spread of Covid19 by improving their service delivery methods and skills to support the fight against the epidemic. In combating the epidemic, when the general view of local governments is examined, especially in countries where localization is robust, it is observed that these units are very useful in-service delivery and decision-making processes.

In countries where centralization is stronger such as Turkey, it is one of the main views that has emerged in the researches and studies that the decisions coming from the center rather than the local in the process of combating the epidemic are more decisive and effective in the general operation and at the point of producing solutions to the needs. In the period of combating the epidemic, the actions and activities of the central government to intervene in the innovative solution proposals and service delivery methods produced by local governments for the emerging needs and control the process support this view. In this context, the process of fighting the epidemic in Turkey rather than local government, central government more possible to have the control. 
Despite limited resources and the central government's control, local governments in Turkey have produced qualified local solutions to emerging needs in the fight against the epidemic. Thus, they made important contributions to the process and made strong efforts in this direction.

Within the scope of the new type of coronavirus epidemic that affects the whole world, researching the services offered by local governments that are responsible for providing the closest service to citizens constitutes the main purpose of this study titled "Overview of the Local Governments in Turkey with Covid-19 in the Process of Combating Covid-19". In this study, metropolitan municipalities, nearly service 78 percent of the population in Turkey within the scope of combating the epidemic have been investigated in detail. In the study, it was tried to include the services and solutions they developed against the new type of coronavirus, the local governments and their practices that are considered as examples of good practice in the international context in the literature. The main objective of the study, in the fight against the epidemic by identifying areas of Turkey and the policies and activities of local governments to combat the epidemic, which has an important place in the world is located in the general conclusions. Also, to contribute to the development of a new policy dialogue in which the participation of all relevant stakeholders in this field can be achieved.

In study, developed by content analysis method, the ways of metropolitan municipalities, which hold the 78 percent of the population, to fight, to provide services and to choose areas of activities against the pandemic have been included. Within the scope of the study, local administrations evaluated from the perspective of good practice examples in the international context; and methods and practices to combat the epidemic were also included. In this way, it has tried to be made in the general implications for Turkey.

In the evaluation part of the findings of the study, the solutions and services offered by metropolitan municipalities in combating the pandemic were investigated.

During this process, it was observed that local governments carried out their services under certain headings. These headings; (i) carrying out disinfection and medicine studies at regularly, (ii) continuing public information activities regarding the process, (iii) producing and distributing local masks, (iv) providing transportation support for healthcare personnel, (v) providing economic support to low-income families. It was noteworthy that they tried to support the process by diversifying and improving their service delivery 
methods. When the practices developed and carried out by local governments, which are evaluated within the scope of good practice examples in the international context in the literature, for the process of combating the epidemic are examined; (i) strengthening digital and technical infrastructures, (ii) measuring the mobility of citizens with spatial-based monitoring systems in the context of smart city applications, (iii) social support and assistance services, (iv) supporting social policy applications and health studies come to the fore. It has been observed that they prioritize services.

In this study, Turkey and international best practices developed in the fields of activity covered by the local authorities' fight the epidemic has been evaluated, and the process of combating the epidemic of local governments in Turkey has led many successful implementations. However, in this process, the central government in Turkey, the control and intervention for some of the local government's actions and activities, was determined to be excessive.

\section{Kaynakça/References}

7244 Sayılı Yeni Koronavirüs (COVID-19) Salgınının Ekonomik Ve Sosyal Hayata Etkilerinin Azaltılması Hakkında Kanun İle Bazı Kanunlarda Değişiklik Yapılmasına Dair Kanun (2020, 16 Nisan) T. C. Resmi Gazete, (Say1 31102).

Adana Büyükşehir Belediyesi. (2020). Çiftçilere ve balıķılara nakdi hibe yardım desteği. 9 Temmuz 2020 tarihinde https://www.adana.bel.tr/panel/uploads/duyuru_v/dosya/ciftcilere-ve-balikcilara-nakdi-hibe-yardim-destegi.pdf adresinden alınd.

Alert Swiss. (2020). Coronavirus-all of Switzerland. 11 Eylül 2020 tarihinde https://www.alert.swiss/en/home.html adresinden alındı.

Amerika'nun Sesi. (2020). Sokaktan beş yıldızl otele. 09 14, 2020 tarihinde https://www.amerikaninsesi.com/a/sokaktan-bes-yildizli-otele-new-york-evsizler-korona-corona-abd-metro/5413134.html adresinden alınd.

Ankara Büyükşehir Belediyesi kiracılarının borçları 2 ay ertelendi. (2020). CNNTÜRK. 5 Mayıs 2020 tarihinde https://www.cnnturk.com/turkiye/ankara-buyuksehir-belediyesi-kiracilarinin-borclari-2-ay-ertelendi adresinden alınd1.

Ankara Büyükşehir Belediyesi. (2020a). 6 milyon tek yürek oldu tüm su faturaları ödendi. 13 Ağustos 2020 tarihinde https://www.ankara.bel.tr/haberler/6-milyon-tek-yurek-oldu-tum-su-faturalari-odendi/ adresinden alındı.

Ankara Büyükşehir Belediyesi. (2020b). Başkan Yavaş'tan çocuklara eğitim desteği. 13 Ekim 2020 tarihinde https://www.ankara.bel.tr/haberler/baskan-yavastan-cocuklara-egitim-destegi/ adresinden alındı.

Aydın Büyükşehir Belediyesi. (2020). Aydın Büyükşehir Belediyesi hallerde hijyeni sağhlyor. 30 Ağustos 2020 tarihinde http://aydin.bel.tr/detail/9034/aydin-buyuksehirbelediyesi-hallerde-hijyeni-sagliyor adresinden alındı. 
Balıkesir Büyükşehir Belediyesi. (2020). Büyükşehir, üreticilere desteğgi artırdı. 12 Ağustos 2020 tarihinde https://www.balikesir.bel.tr/haberler/buyuksehir-ureticilere-destegi-artirdi adresinden alındı.

Barcelona.Cat. (2020). Extraordinary contribution of 2.5 million euros for rent payments. 11 Eylül 2020 tarihinde https://www.barcelona.cat/infobarcelona/en/tema/information-about-covid-19/extraordinary-contribution-of-2-5-million-euros-for-rentpayments_952286.html\# adresinden alınd.

Bayraktar, U. (2020). Pandemide ve sonrasında yerel yönetimler için politika önerileri. 15 Eylül 2020 tarihinde İstanbul Politik Araştırmalae Enstitüsü: https://www.istanpol.org/post/pandemide-ve-sonras $\%$ C4\%B1nda-yerel-y\%C3\%B6netimleri\%CC\%87\%C3\%A7in-politika-\%C3\%B6nerileri adresinden alındı.

Bursa Büyükşehir Belediyesi. (2020). Bursa Büyükşehir Belediyesi COVID -19 normalleşme eylem plan: 1 Haziran-30 Eylül. 1 Eylül 2020 tarihinde http://www.skb.gov.tr/wp-content/uploads/2020/06/BBB-COVID-19-NORMALLESME-EYLEM-PLANI.pdf adresinden alındı.

Bursa Büyükşehir Belediyesi. (2020). Evde konser zamanı. 12 Eylül 2020 tarihinde https://www.bursa.bel.tr/evde-konser-zamani/haber/28876 adresinden alındı.

Capital İnitiatives for COVID-19. (2020). Capital Initiatives for COVID-19. https:/www.capitalsinitiative.org/tr/2020/05/02/atina-sehrinin-covid-19a-karsionlemleri/ adresinden alınd.

City of Helsinki. (2020). Helsinki offers free warm meals for the homeless. 13 Eylül 2020 tarihinde https://www.hel.fi/uutiset/en/social-services-and-health-care/helsinkito-start-warm-meal-service-for-the-homeless adresinden alınd.

Denizli Büyükşehir Belediyesi. (2020). 23 Nisan coşkusu Büyükşsehir Bandosu ile yaşanacak. 12 Mayıs 2020 tarihinde https://www.denizli.bel.tr/Default.aspx?k=haber-detay\&id=19681 adresinden alınd1.

Diyarbakır Büyükşehir Belediyesi. (2020). Büyükşshir Belediyesi evde çekilen en iyi fotoğrafları ödüllendiriyor. 12 Eylül 2020 tarihinde http://www.diyarbakir.bel.tr/haberler/1799-spordaire.html adresinden alınd.

Ensitü İstanbul . (2020). Dünya Kentlerinde Yerel Yönetimlerin COVID-19 Önlemleri. 11 Ağustos 2020 tarihinde https:/enstitu.ibb.istanbul/covid19/yerel-yonetimler/ adresinden alındi.

Erdoğan, E. (2020). TESEV değerlendirme notlart: Türkiye'de koronavirüs günleri:Despotik Leviathan'ın gölgesinde yönetişim kavramm düşünmek. 12 Eylül 2020 tarihinde https://www.tesev.org.tr/wp-content/uploads/TESEV_Degerlendirme_Notlari_Emre_Erdogan_Koronavirus_Gunlerinde_Yonetisim.pdf adresinden alınd1.

Erzurum Büyükşehir Belediyesi. (2020). Büyükşshir denetime yoğunlaştı. 7 Eylül 2020 tarihinde https://www.erzurum.bel.tr/GuncelHaber-buyuksehir-denetime-yogunlasti/29/829727.html adresinden alınd1.

Eskişehir Büyükşehir Belediyesi. (2020). Eskişehir Büyükşehir COVID-19 eylem planın kararlılıla uyguluyor.11 Eylül 2020 tarihinde http://cepte.eskisehir.bel.tr/icerik_dvm.php?icerik_id=5676\&cat_icerik=1\&menu_id=24 adresinden alınd. 
Gaziantep Büyükşehir Belediyesi. (2020). Büyükşehir işbirliğinde kurulan çağrı merkezi için eğitimlere başlandı. 09 01, 2020 tarihinde https://gaziantep.bel.tr/tr/haberler/buyuksehir-is-birliginde-kurulan-cagri-merkezi-icin-egitimlere-baslandi adresinden alınd1.

Gözübüyük, Ş. (2008). T.C. 1982 Anayasası. Ankara: Turhan Kitabevi Ofset.

Hatay Büyükşehir Belediyesi. (2020). Hatay Büyükşehir, korona virüs denetimlerini sürdürüyor. 11 Eylül 2020 tarihinde https://www.haberturk.com/hatay-haberleri/80221999-hatay-buyuksehir-korona-virus-denetimlerini-surduruyor adresinden alındi.

İstanbul Büyükşehir Belediyesi. (2020a). Askıda fatura. 9 Temmuz 2020 tarihinde https://askidafatura.ibb.gov.tr/ adresinden alınd1.

İstanbul Büyükşehir Belediyesi. (2020b). İstanbul Bülteni: IBB dört koldan koronavirüs ile mücadele ediyor. 12 Ağustos 2020 tarihinde https://www.ibb.istanbul/Uploads/2020/4/istanbul-bulteni-nisan-2020-korona.pdf adresinden alındı.

İstanbul Büyükşehir Belediyesi. (2020c). Pandemi döneminde İBB'den Halk sağhığına psikolojik destek. 13 Eylül 2020 tarihinde https://www.ibb.istanbul/News/Detail/36602 adresinden alındı.

İzmir Büyükşehir Belediyesi. (2020a). İzmir Büyükşehir Belediyesi COVID-19 dirençlilik eylem planı. 12 Temmuz 2020 tarihinde https:/www.izmir.bel.tr/CKYuklenen/Covid19DirenclilikEylemPlani_TR.pdf adresinden alındı.

İzmir Büyükşehir Belediyesi. (2020b). İzmir'in metro istasyonlarında maskematik dönemi. 15 Eylül 2020 tarihinde https://www.izmir.bel.tr/tr/Haberler/izmir-in-metro-istasyonlarinda-maskematik-donemi/43494/156 adresinden alındı.

Kahramanmaraş Büyükşehir Belediyesi. (2020). Büyükşehir'den meydanlara dezenfekte hizmeti. 11 Ağustos 2020 tarihinde https://kahramanmaras.bel.tr/haber/2020/03/14/buyuksehirden-meydanlara-dezenfekte-hizmeti adresinden alındi.

Kap, D. (2020a). Yerel Yönetimlerin Pandemiyle Mücadelesi (1) "IYYKM Eşgüdüm ve Koordinasyon Sağlıyor". 15 Eylül 2020 tarihinde https://www.sivilsayfalar.org/2020/04/20/yerel-yonetimlerin-pandemiyle-mucadelesi-1-iykm-esgudumve-koordinasyon-sagliyor/ adresinden alınd1.

Kap, D. (2020b). Yerel Yönetimlerin Pandemiyle Mücadelesi (4) Salgınla Mücadelede Bütünlüklü Bir Politika Gerekli. 15 Eylül 2020 tarihinde https://www.sivilsayfalar.org/2020/05/08/yerel-yonetimlerin-pandemiyle-mucadelesi-4-salginla-mucadelede-butunluklu-bir-politika-gerekli/ adresinden alındı.

Kayseri Büyükşehir Belediyesi. (2020). Sokak hayvanlarımızı da unutmadık. https://www.tbb.gov.tr/birligimiz/mudurlukler/proje-ve-finansman-birimi/covid-19/belediyelerimizden-covid-19-haberleri/kayseri-buyuksehir-belediyesi-sokak-hayvanlarini-unutmadi/ 12 Eylül 2020 tarihinde Kayseri Büyükşehir Belediyesi adresinden alındı. 
Kayseri'de Spor A.Ş.'den vatandaşlara canlı spor eğitimi. (2020). Hürriyet. 3 Eylül 2020 tarihinde https://www.hurriyet.com.tr/sporarena/kayseride-spor-a-s-den-vatandaslara-canli-spor-egitimi-41482452 adresinden alındı.

Kocaeli Büyükşehir Belediyesi. (2020). Kocaeli Büyükşehir Belediyesi barnmma merkezinde sağlık taraması yaptı. 9 Eylül 2020 tarihinde https:/www.tbb.gov.tr/basin-ve-yayin/covid-19/belediyelerimizden-covid-19-haberleri/kocaeli-buyuksehir-belediyesi-barinma-merkezinde-saglik-taramasi-yapti adresinden alındı.

Konya Su ve Kanalizasyon İdaresi Genel Müdürlüğü. (2020). Konya Büyükşehir'den Koronavirüs tedbirler. 12 Ağustos 2020 tarihinde https://www.koski.gov.tr/haber/konya-buyuksehir--039-den-koronavirus-tedbirleri-2020-03-16-58 adresinden alindi.

Konya Su ve Kanalizasyon İdaresi Genel Müdürlüğü. (2020). Konya Büyükşehir'den Koronavirüs Tedbirleri. 11 Eylül 2020 tarihinde https://www.koski.gov.tr/haber/konya-buyuksehir--039-den-koronavirus-tedbirleri-2020-03-16-58 adresinden alind1.

Kron4. (2020). San Francisco ups access to WiFi hotspots to support distance learning during pandemic. 12 Mayss 2020 tarihinde https://www.kron4.com/news/bay-area/sanfrancisco-to-increase-access-to-wifi-hotspots-to-support-distance-learning-during-pandemic/ adresinden alınd1.

Malatya Büyükşehir Belediyesi. (2020). 600 bin maske Büyükşehir Belediyesine teslim edildi. 11 09, 2020 tarihinde http://m.malatya.bel.tr/icerik/18/7989/600-bin-maskebuyuksehir-belediyesine-teslim-edildi.aspx adresinden alındı.

Mardin Büyükşehir Belediyesi. (2020). Büyükşehir Belediye zabıtasından HES kodu denetimi. 08 19, 2020 tarihinde https://www.mardin.bel.tr/tr-tr/haber/buyuksehir-belediye-zabitasindan-hes-kodu-denetimi/104375 adresinden alınd.

Medyabar. (2020). Taburcu Olan Hastalara Büyükşehir'den ulaşım desteği. 12 08, 2020 tarihinde https://medyabar.com/haber/4309693/taburcu-olan-hastalara-buyuksehirden-ulasim-destegi adresinden alındı.

Mersin Büyükşehir Belediyesi. (2020). Büyükşehir'den personele "ebeveyn farkındalık eğitimi". 13 Eylül 2020 tarihinde https://www.mersin.bel.tr/haber/buyuksehir-denpersonele-ebeveyn-farkindalik-egitimi adresinden alınd1.

More than 1,000 of London's homeless off the streets to self-isolate in hotels or safe locations during lockdown. (2020). Daily Mail Online. 15 Eylül2020 tarihinde https://www.dailymail.co.uk/news/article-8217315/1-000-homeless-people-London-self-isolating-hotels-amid-coronavirus-lockdown.html adresinden alındı.

Muğla Büyükşehir Belediyesi. (2020). Büyükşehir, sosyal hizmetleriyle ihtiyaç sahibi vatandaşların yanında. 13 Eylül 2020 tarihinde https://www.mugla.bel.tr/haber/buyuksehir-sosyal-hizmetleriyle-ihtiyac-sahibi-vatandaslarin-yaninda adresinden alınd.

My Paris. (2020). 2,000 Protective visors for city officials. 12 Eylül 2020 tarihinde https://www.paris.fr/pages/2000-visieres-de-protection-pour-les-agents-de-laville-7748 adresinden alınd. 
My Paris. (2020). Paris at home: videos to stay in shape! 12 Eylül 2020 tarihinde https://quefaire.paris.fr/104557/paris-chez-vous-des-videos-pour-rester-en-forme adresinden alındı.

Official website of the Mayor of Moscow. (2020). Coronavirus:Official information. 08 30, 2020 tarihinde https://www.mos.ru/city/projects/covid-19/?onsite_molding=1 adresinden alındı

Pektaş, E. K. (2010). Türkiye'de sosyal belediyecilik uygulamaları ve temel sorunlar. Akademik Incelemeler Dergisi, 2(16), 1-22.

Samsun Büyükşehir Belediyesi. (2020). Samsun Büyükşehirden 'tıbbi atık' seferberliği! 09 13, 2020 tarihinde https:/www.tbb.gov.tr/basin-ve-yayin/covid-19/belediyelerimizden-covid-19-haberleri/samsun-buyuksehirden-tibbi-atik-seferberligi adresinden alındı.

Sivil Sayfalar. (2020a). Yerel yönetimlerin pandemiyle mücadelesi (2): Izmir'de kriz belediyeciliği. 11 09, 2020 tarihinde https://www.sivilsayfalar.org/2020/04/24/yerel-yonetimlerin-pandemiyle-mucadelesi-2-izmirde-kriz-belediyeciligi/ adresinden alındı.

Sivil Sayfalar. (2020b). Yerel yönetimlerin pandemiyle mücadelesi (4) salginla mücadelede bütünlüklü bir politika gerekli. 8 Haziran 2020 tarihinde https://www.sivilsayfalar.org/2020/05/08/yerel-yonetimlerin-pandemiyle-mucadelesi-4-salginla-mucadelede-butunluklu-bir-politika-gerekli/ adresinden alındı.

Şanlıurfa Büyükşehir Belediyesi. (2020). Büyükşehir ilçelere dezenfekte istasyonları kuruyor. 09 16, 2020 tarihinde https://www.sanliurfa.bel.tr/icerik/9553/21/buyuksehirilcelere-dezenfekte-istasyonlari-kuruyor adresinden alındı

T.C. Ankara Büyükşehir Belediyesi. (2020). Ankara Büyükşehir Belediyesi olarak dünya basmm tarıoruz, belediye olarak hem kendimiz bilgileniyoruz hem de sizi bilgilendiriyoruz .. 11 Ağustos 2020 tarihinde http://www.ankara.bel.tr/haberler/duyuru7?fbclid=IwAR3BzUaqs6ib1e35LNCh0rDxNcAbL0qZQuMLDW8N9bJR_95b8mShA6uhuw adresinden alınd1.

T.C. İçişleri Bakanlığı. (2020a). 81 İl Valiliği'ne koronavirüs tedbirleri konulu ek genelge gönderildi. 09 08, 2020 tarihinde https://www.icisleri.gov.tr/81-il-valiligine-koronavirus-tedbirleri-konulu-ek-genelge-gonderildi-08-09-20 adresinden alınd1.

T.C. İçişleri Bakanlığı. (2020c). Yardım toplama hususuna ilişkin kamuoyu bilgilendirmesi. 12 Mayıs 2020 tarihinde https://www.icisleri.gov.tr/yardim-toplanmasi-hususuna-iliskin-kamuoyu-bilgilendirmesi adresinden alınd1.

T.C. Sağlık Bakanlığı. (2020). Sağhlk çalışanlarına ücretsiz ulaşım ve konaklama ile ilgili düzenleme yapıldı. 13 Haziran 2020 tarihinde https://yhgm.saglik.gov.tr/TR,64663/saglik-calisanlarina-ucretsiz-ulasim-ve-konaklama-ile-ilgili-duzenleme-yapildi.html adresinden alındı.

Tekirdağ Büyükşehir Belediyesi. (2020). Büyükşehir Belediyesi kovid-19'la etkin mücadelesini sürdürüyor. 3 Eylül2020 tarihinde http://www.tekirdag.bel.tr/haber/31246 adresinden alınd 1 
The Governing Mayor of Berlin. (2020). Coronavirus Information (COVID-19). 12 Eylül 2020 tarihinde https:/www.berlin.de/corona/en/testing-facilities/ adresinden alınd1.

Trabzon Büyükşehir Belediyesi. (2020). Büyükşehir'den sosyal yardım atağı. 08 12, 2020 tarihinde https://www.trabzon.bel.tr/haber-detay.aspx?id=32495 adresinden alındi.

Türkiye Belediyeler Birliği. (2020a). Antalya Büyükşehir Belediyesi'nden halkı bilinçlendirme çalışması. 14 Eylül 2020 tarihinde https:/www.tbb.gov.tr/basin-ve-yayin/covid-19/belediyelerimizden-covid-19-haberleri/antalya-buyuksehir-belediyesinden-halki-bilinclendirme-calismasi adresinden alındı.

Türkiye Belediyeler Birliği. (2020b). Manisa'da Koronavirüs seferberliği. 08 22, 2020 tarihinde https://www.tbb.gov.tr/basin-ve-yayin/covid-19/belediyelerimizden-covid19-haberleri/manisada-koronavirus-seferberligi adresinden alınd.

Türkiye Belediyeler Birliği. (2020c). Mardin'de Illköğretim öğrencilerine kitap hediye ediliyor. 12 Eylül 2020 tarihinde https://www.tbb.gov.tr/basin-ve-yayin/covid-19/belediyelerimizden-covid-19-haberleri/mardinde-ilkogretim-ogrencilerine-kitap-hediye-ediliyor adresinden alındı

Türkiye Belediyeler Birliği. (2020d). Ordu Büyükşshirden online satranç turnuvası/satrançseverler bu turnuvayı kaçırmayın. 7 Mayıs 2020 tarihinde https://www.tbb.gov.tr/basin-ve-yayin/covid-19/belediyelerimizden-covid-19-haberleri/ordu-buyuksehirden-online-satranc-turnuvasisatrancseverler-bu-turnuvayi-kacirmayin adresinden alındı.

Türkiye Bilimler Akademisi. (2020). Covid-19 pandemi değerlendirme raporu. İstanbul: Türkiye Bilimler Akademisi Yayınları.

Türkiye Psikayatri Derneği. (2020). Koronavirüs hastahı̆ı salgını sırasında ruh sağhlğı ve stresle baş etme. 17 Nisan 2020 tarihinde https://www.psikiyatri.org.tr/2147/koronavirus-hastaligi-salgini-sirasinda-ruh-sagligi-ve-stresle-bas-etme adresinden alındi.

Van Büyükşehir Belediyesi. (2020). Büyükşehir Belediyesi'nden yoğun hasta nakil mesaisi. 5 Eylül 2020 tarihinde https://van.bel.tr/HaberDetay/buyuksehir-belediyesindenyogun-hasta-nakil-mesaisi-18042020181145.html adresinden alınd.

World Health Organization. (2020). COVID-19 hastalı̆̆ında maske kullanımına ilişkin öne. 6 Mayıs 2020 tarihinde https://www.ttb.org.tr/userfiles/files/WHO-maske.pdf adresinden alındi.

Wyndhamcity. (2020). COVID 19 - council services. 15 Nisan 2020 tarihinde https://www.wyndham.vic.gov.au/COVID19 adresinden alınd.

Yeni Haber. (2020). Ankara Büyükşehir Belediyesinden evlere temizliğe giden kadınlara gıda ve nakit desteği. 5 Eylül 2020 tarihinde https://www.yenihaberden.com/ankara-buyuksehir-belediyesinden-evlere-temizlige-giden-kadinlara-gida-ve-nakit-des1484631h.htm adresinden alınd. 